\title{
TEKNOLOGI BRANDING DALAM PENGEMASAN PRODUK EMPING MELINJO UPAYA MENINGKATKAN PARTISIPASI, KETERAMPILAN DAN PEMASARAN MASYARAKAT PEDESAAN DI DESA MANCAK, KECAMATAN MANCAK KABUPATEN SERANG
}

\author{
Edy Nasri \\ Universitas Banten Jaya, Jl Syech Nawawi Albantani Serang, Banten, Indonesia \\ Email: edynasri@unbaja.ac.id
}

\begin{abstract}
The purpose of the Student Work Lecture Community Service Program is as Learning and Empowerment for the Community in order to improve skills and help increase sales of products produced by the Village community. The products produced by the special community of Mancak Village are emping melinjo is a typical and iconic product of tourism in Serang Regency as the village center of emping melinjo. The problem faced is that the production processing is still done traditionally and attractive packaging has not been made and the customer is still doing it by selling to middlemen / collectors. as a result, the marketed production is still small and the attributes of the melinjo chips product are still simple, there are not many variations, causing a low selling value. The method that is used to develop this community service implementation is through (1) Survey through observation, interviews, and analysis of problems and village potentials, (2) Graphic Design Training, (3) packaging manufacturing training using branding technology. From the results of implementation through community service programs, the increase in community knowledge and skills regarding (1) Utilizing multimedia, and (2) making packaging with branding technology. In this activity, it is expected to increase knowledge and skills in branding technology for packaging processing and increasing product sale value, so that the people of Mancak Village become productive and active people.
\end{abstract}

Keywords : Packaging; Branding; Learning Community Empowerment; Emping Melinjo.

\begin{abstract}
Abstrak
Tujuan dari Program Pengabdian Masyarakat Kuliah Kerja Mahasiswa sebagai Pembelajaran dan Pemberdayaan Kepada Masyarakat agar meningkatkan keterampilan dan membantu meningkatkan penjualan produk yang dihasilkan oleh masyarakat Desa. Produk yang dihasilkan masyarakat khusus Desa Mancak adalah emping melinjo merupakan produk khas dan ikon dari parawisata Kabupaten Serang sebagai desa centra emping melinjo. Permasalahan yang dihadapi yaitu dalam pengolahan produksi masih dilakukan tradisional dan belum dibuat kemasan yang menarik serta pemasanya masih dilakukan dengan cara menjual ke tengkulak/ pengepul, akibatnya produksi yang dipasarkan masih sedikit serta atribut-atribut dari produk emping melinjo masih sederhana belum banyak pariasi menimbulkan nilai jual yang rendah. Metode yang dekembangkan pelaksanaan pengabdian masyarakat ini yaitu melalui (1) Survey melalui pengamatan, wawancara, dan analisis permasalahan dan potensi desa, (2) Pelatihan Design Grafis, (3) pelatihan pembuatan kemasan dengan teknologi branding. Dari hasil pelaksanaan melalui program pengabdian maysarakat adalah bertambahnya pengetahuan dan keterampilan masyarakat mengenai (1) Memanfaatkan multimedia, dan (2) membuat kemasan dengan teknologi branding. Dalam kegaitan ini diharapkan dapat meningkatkan pengetahuan dan keterampilan dalam teknologi branding untuk pengolahan kemasan dan meningkatkan nilai jual produk, sehingga masyarakat Desa Mancak menjadi masyarakat yang produktif dan keatif.
\end{abstract}

Kata Kunci : Pengemasan; Branding; Pembelajaran; Pemberdayaan Masyarakat; Emping Melinjo. 


\section{PENDAHULUAN}

Desa Mancak adalah sebuah desa dari kecamatan Mancak di Kabupaten Serang, Provinsi Banten, yang secara geografis termasuk pengembangan dari Serang Barat, dengan luas wilayah $72,03 \mathrm{~km}^{2}$ (7403 Ha) terletak diantara ketinggian 250m diatas permukaan laut dengan curah hujan rata-rata 0,05 $\mathrm{mm}$ pertahun, dengan jarak tempuh kurang dari $30 \mathrm{~km}$ dari ibu kota Kabupaten dan ibu kota Provinsi dan jarak ke ibu kota Negara lebih kurang 120 km. Letak geografi Desa Mancak, terletak Sebelah Utara : Desa Batukuda, Sebelah Selatan: Desa Labuan, Sebelah Barat :Desa Labuan dan Setelah Timur: Desa Waringin. Wilayah ini sebagian besar wilayah perkebunan dan pertanian sebagian besar pertanian menghasilkan Tangkil/ Melinjo dari hasil kebun mereka biasanya langsung dijual di tengkuak atau pengepul dimana masih mengunakan cara tradisional sehinga dalam pemasaran produk mereka hanya sebatas dari desa kedesa atau dikumpulkan biasanya juga pembeli mendatangi rumah-rumah penduduk.

Dari latarbelakang diatas maka kegaitan pengabdian masyarakat ini bagaimana caranya menrapkan Teknologi Branding Dalam Pengemasan Produk Emping Melinjo Upaya Meningkatkan Partisipasi, Keterampilan dan Pemasaran Masyarakat Pedesaan di Desa Mancak, Kecamatan Mancak Kabupaten Serang. Tujuan dari Program Pengabdian Masyarakat sebagai Pembelajaran dan Pemberdayaan Kepada Masyarakat agar meningkatkan keterampilan dan membantu meningkatkan penjualan produk yang dihasilkan oleh masyarakat Desa, manfaat pengabdian kepada Masyarakat ini adalah memberikan atas pemahaman serta ketrampilan dalam mendisain sebuah branding dalam pengemasan emping melinjo agar dapat bersaing di dunia industri serta bisa masuk ke pasar global.

\section{TINJAUAN PUSTAKA}

1. Teknologi Branding

Naisbitt (2002) mengutip pemahaman tentang teknologi dari Random House Dictionary, yang mengatakan bahwa teknologi adalah obyek serta benda-benda, serta bahan dan bentuk juga berbeda dari manusia biasa.

Brand (Merek) merupakan "Nama, istilah, lambang, atau desain, atau kombinasinya, yang dimaksudkan untuk mengidentifikasi barang atau jasa dari salah satu penjual atau kelompok penjual dan mendiferensiasikan mereka dari pesaing”, Kolter, Philip dan Kevin Lane Keller. (2009:172), Sedangkan menurut undang-undang Merek Dan Indikasi Geografis Nomor 20 Tahun 2016 pasal 1 ayat 1 : Merek adalah tanda yang dapat ditampilkan secara grafis berupa gambar, logo, nama, kata, huruf, angka, susunan warna, dalam bentuk 2 (dua) dimensi 
dan/atau 3 (tiga) dimensi, suara, hologram, atau kombinasi dari 2 (dua) atau lebih unsur tersebut untuk membedakan barang dan/atau jasa yang diproduksi oleh orang atau badan hukum dalam kegiatan perdagangan barang dan/atau jasa.

Bagian-bagian merek diunkapkan oleh Kolter, Philip dan Kevin Lane Keller. (2009:76), yaitu : a. brand name adalah sebagian dari merek dan yang diucapkan. b. brand merk adalah sebagian dari merek yang dapat dikenal, tetapi tidak dapat diucapkan, seperti lambang desain, huruf, atau warna khusus c. trademark adalah merek atau sebagian dari merek yang dilindungi hukum karena kemampuannya menghasilkan sesuatu yang istimewa. d. copyright adalah hak istimewa yang dilindungi undang-undang untuk memproduksi, menertibkan, dan menjual karya tulis, karya musik, atau karya seni.

Dari pendapat diatas maka merek merupakan demensi dari nama, kata, huruf, warna dan simbol yang bisa mengidentifikasikan sebuah produk barang atau jasa.

2. Pengemasan

pengemasan adalah kegiatan merancang dan memproduksi wadah atau bungkus sebagai sebuah produk. Pengemasan adalah aktivitas merancang dan memproduksi kemasan atau pembungkus untuk produk. Biasanya fungsi utama dari kemasan adalah untuk menjaga produk, Menurut Kotler \& Keller (2009:27), Namun, sekarang kemasan menjadi faktor yang cukup penting sebagai alat pemasaran (Rangkuti, 2010:132).

Menurut (Klimchuk dan Krasovec, 2006:33), Kemasan adalah desain kreatif yang mengaitkan bentuk, struktur, material, warna, citra, tipografi dan elemen-elemen desain dengan informasi produk agar produk dapat dipasarkan. Kemasan digunakan untuk membungkus, melindungi, mengirim, mengeluarkan, menyimpan, mengidentifikasi dan membedakan sebuah produk di pasar

Dari pendapat diatas bisa diuraikan sebagai berikut, Kemasan merupakan bagian awal dari produk yang disajikan kepada konsumen atau pembeli serta mampu menarik atau memikat pembeli. Dalam pengemasan produk biasanya dilakukan oleh produsen untuk dapat memikat atau merebut konsumen terhadap pembelianan suatu produk. Produsen selalu berusaha memberikan kesan yang baik dan menarik pada kemasan produknya yang ditawarkan dan serta menciptakan sebuah model kemasan terbaharu yang harus berbeda dengan produsen sejenis lainya lain dalam menarik pangsa pasar diamana dirancang yang lebih baik dan menarik untuk membangun banding serta mengembangkan ekuitas merek guna mendorong dan meningkatkan penjualan yang maksimum. 


\section{METODE}

Dalam kegaitan pengabdian masyarakat ini kami mengunakan metode pendampingan dan konsultasi kepada masyarakat desa mancak serta pejabat kabupaten yang memberikan masukan kepada kami. Metode kegatanya melalui layanan litrasi, asistensi, bimbingan, konsultasi dan pelatian bersama masyarakat maupun training di ruangan mengenai Teknologi Branding dalam pembuatan kemasan yang lebih baik dan menarik baik dari sisi untuk penjualan maupun dari sisi penigkatan kunjungan prawisata.

\section{HASIL DAN PEMBAHASAN}

Branding merupakan proses untuk memperluas peluang dalam proses disiplin dalam kesadaran konsumen untuk mengunakan atau kesetiaan dalam merek produk tertentu daripada mengunakan produk yang lainya. Dalam kegaitan pemasaran perusahan besar mereka akan peduli dengan branding karna akan mengingkatkan daya saing mereka, begitu pula dengan perusahaan menegah dan usaha kecil atau produk rumahan perlu teknologi branding dalam pengemasan produk mereka, agar brend bisa dikenal masyarakat luas maka membuat tagline dan logo untuk produk emping melinjo.

\section{Pembekalan Kepada Mahasiswa Pendamping Lapangan}

Kegiatan dimulai dari pemberian pembekalan kepada mahasiswa sebagai pendamping lapangan agar semua materi pelatihan dan tujuan dari kegiatan ini tercapai dengan harapan yang baik yang akan dilaksanakan di Desa Mancak, Kecamatan Mancak, Kabupaten Serang. Dalam hal ini materi yang disampaikan adalah Teknologi Branding dengan pelatihan design grafis dalam pengemasan produk emping melinjo, diamana daerah tersebut terkenal dengan penghasil melinjo/ tangkil tetapi dari hasil perkebuan tersebut belum bisa menembus pasar global dikarnakan masih dipasarkan secara tradisional dengan menjual ke pengepul atau tengkulak.
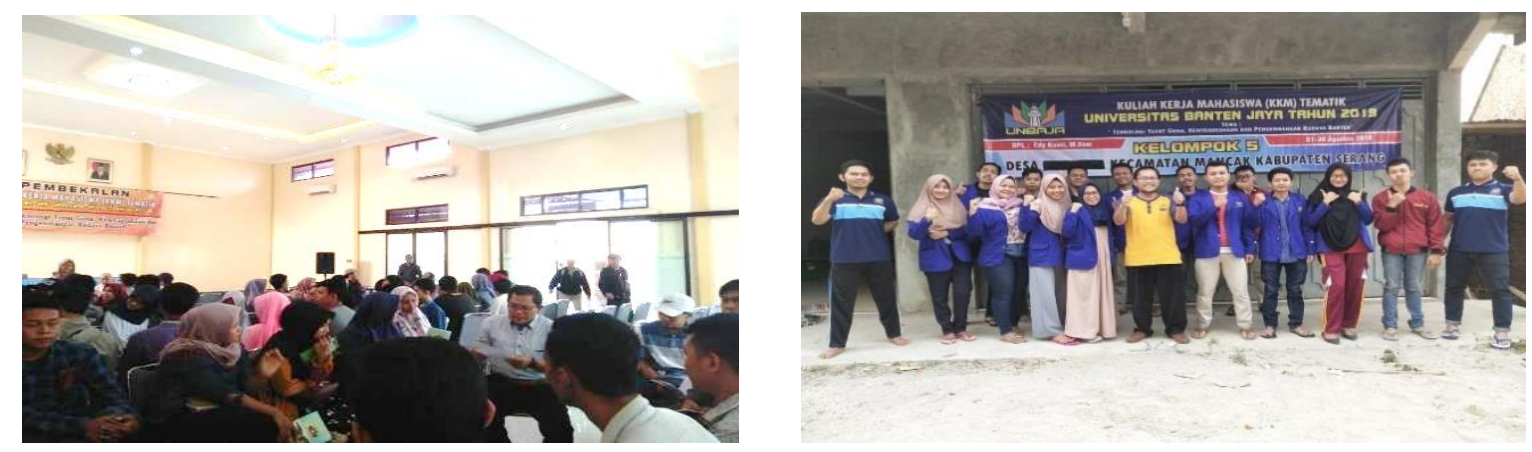

Gambar 1: Pembekalan dan Persiapan Pelaksaaan KKM 
Pembekalan ini yang dibahas dengan manfaat dan tujuan dari Branding pengemasan produk sebagai berikut :

- Branding dalam pengemasan agar lebih dikenal, membuat brand dari emping melinjo akan menciptakan intraksi antara usaha kecil dengan pelangan, dari brand tersebut para pembeli akan mudah mengingat serta menyebabkan efek terkenal kepada para pembeli serta akan menyebarkan berita ke masyarakat baik langsung maupun melalui teknologi media sosial.

- Branding dalam pengemasan agar menarik, membuat brand emping melinjo dan menciptakan ketertarikan dari pelangan karna di design khusus dengan pengemasan yang baik membuat usaha kecil bisa langsung menjual produk mereka baik melalui toko, rekanan, web maupun social media lainya dikarnakan dari sisi kemasan terlihat professional karna dari design yang menarik.

- $\quad$ Branding dalam pengemasan memberikan kepastian, membuat brand emping melinjo menciptakan kepastian pembeli karna brand akan memberikan keputusan yang baik untuk memastikan bahwa brand tersebut produksinya layak baik untuk di konsumsi dan di pasarkan secara global.

- $\quad$ Branding dalam pengemasan meningkatkan promosi, membuat brand emping melinjo mencipkaan informasi terhadap sebuah produk sebagai sarana promosi untuk meningkatkan daya saing nilai produk dan akan menjadi manfaat juga untuk mengkatkan wisata didaerah tersebut,

- Branding dalam pengemasan membuat produk berbeda dengan produk yang lainya, membuat brand emping melinjo menciptakan sebuah produk yang berbeda dengan produk lainya, didalam strategi Branding untuk pemasaran masyarakat akan lebih yakin terhadap produk yang design, karna design sendiri akan mempengaruhi volume terhadap penjualan baik melalui toko, website maupun melalui media social lainya.

\section{Pelatihan Design Grafis dalam pembuatan Branding Pengmasan Produk}

Kegiatan Berikutnya adalah melakukan pelatihan design grafis dalam pembuatan kemasan produk, Design Grafis merupakan pendekorasian visual menciptakan ilustrasi, tipografi, fotografi, ataupun grafis motion. 

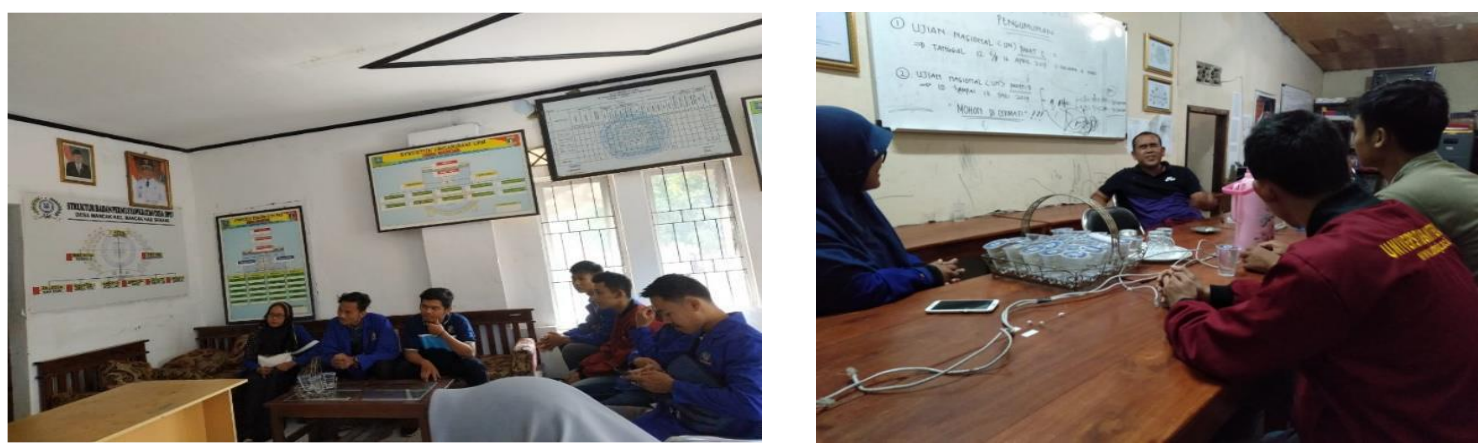

Gambar 2: Diskusi dengan pemangku kepentingan Desa untuk persiapan pelatihan

Desainer grafis menciptakan karya media cetak dan elektronik, seperti halnya brosur dan mengiklankan produk dan lain-lainya, agar Menarik yang bisa diaplikasikan sebagai bentuk salah satu alat untuk melakukan atau membuat branding atau sebagai materi promosi yang berkaitan dengan produk dan publik, Ada beberapa yang perlu jadi perhatikan dalam dalam pelatihan ini adalah :

- Nama Brand atau Merek, Brand atau merek adalah sebagai nama, simbol, istilah, tanda, atau rancangan, atau kombinasi dari semuanya, yang dimaksudkan untuk mengidentifikasikannya dari sebuah produk dari produsen atau pembuat maupun penjual serta mendeferensiasikan dari pada produk laininya agar bisa bersaing dengn pesaing dengan produk sejenisnya.

- Color atau Warna, sangat mempengaruhi proses branding karna warna dari kemasan mampu atau menimbulkan perasaan dan prilaku emosi pada komsumen atau pembeli yang berbeda-beda karna warna mempunyai daya pikat yang luarbiasa untuk menciptkan kesankesan yang sangat mendalam serta bisa bertahan lama suatu produk atau brand. Bahkan warna kemasan bisa mengkomunikasikan, mengambarkan sebuah tampilan-tampilan fiturfitur dan atribut dari sebuah brand produk, jadi warna bisa menciptakan nilai dari promosi dan penjualan.

- Typography, merupakan ilmu pemilihan dan penempatan huruf untuk menciptakan suatu kesan yang mendalam dalam teknologi branding agar mencipatkan informasi yang menarik serta mendapatkan kenyamanan komsumen untuk membaca dan menyebarkan informasi yang baik, typography juga disebut sebagai ilmu "visual language", karna bisa menciptakan visualisasi dari bahasa. 
- Image atau gambar, berfungsi sebagai penarik perhatian untuk memperjelas, mengilustrasikan suatu fakta agar konsumen mudah mengingat. Gambar bisa berupa photo,symbol, ilustrasi maupun karakter sebuah produk.

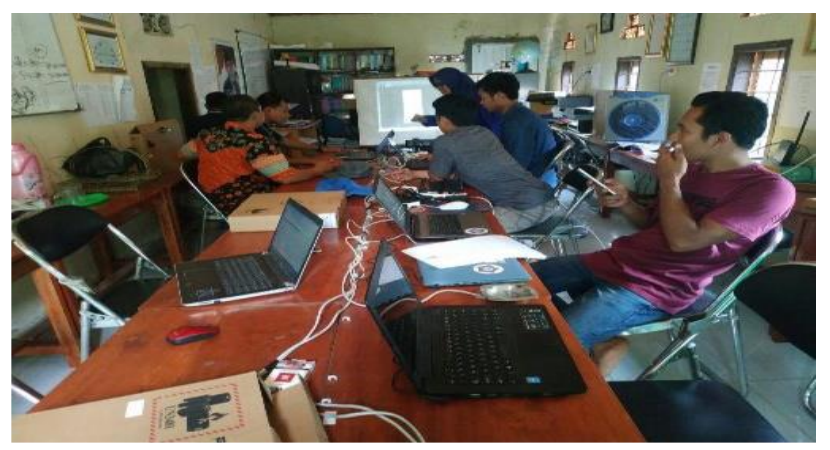

Gambar 3: Pelatihan Design Grafis dengan masyarakat

\section{Peraktek dan hasil}

Dalam melakukan praktek pembuatan emping melinjo team langsung supvey ke kebun melinjo/tangkil serta melihat langsung kegiatan masyarakat membuat emping mulai dari pengunuhan, proses pembuatanya bersama-sama dengan masyarakat desa mancak yang sangat antusias memberikan penjelasan terhadap pembuatan emping melinjo,
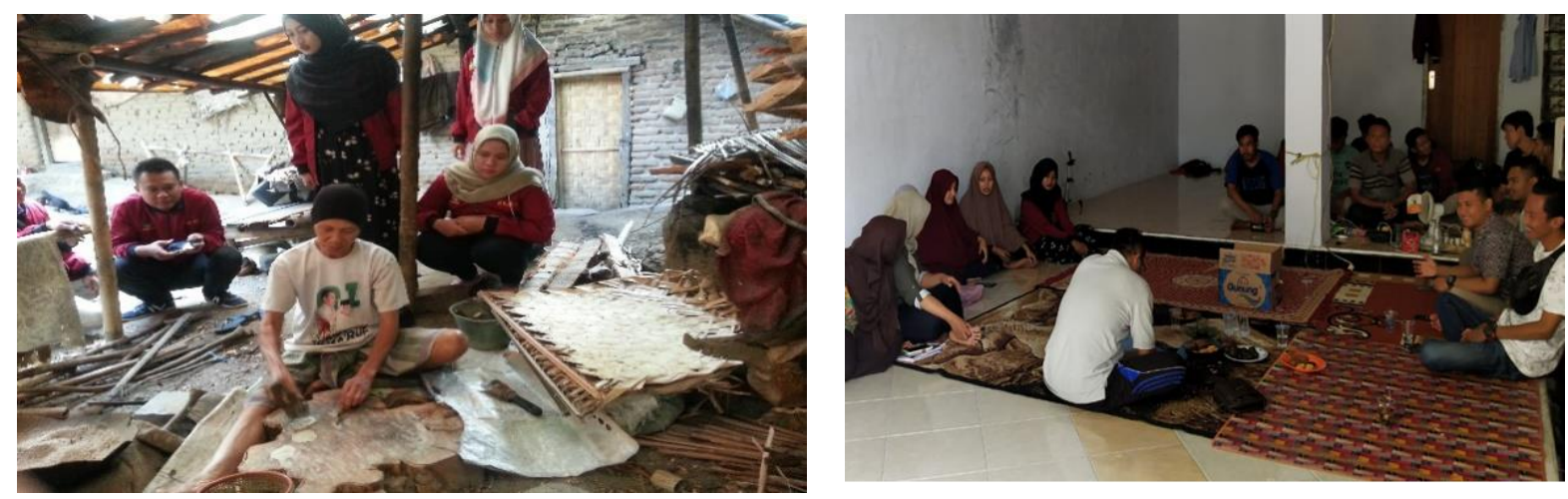

Gambar 4: Praktek Langsung ke tempat pembautan Emping Melinjo dan Rapat

Pembahasan Pembuatan Branding Kemasan Produk

Dari rangkai semua kegiatan program yang kami lakukan mengasilakn sebuah produk branding dalam pengemmasan dengan berbagai kemasan dan citra rasa ada Joprek, Ciplis, Kece dan lain-lain yang kemasanya menarik serta citra rasa yang tinggi 

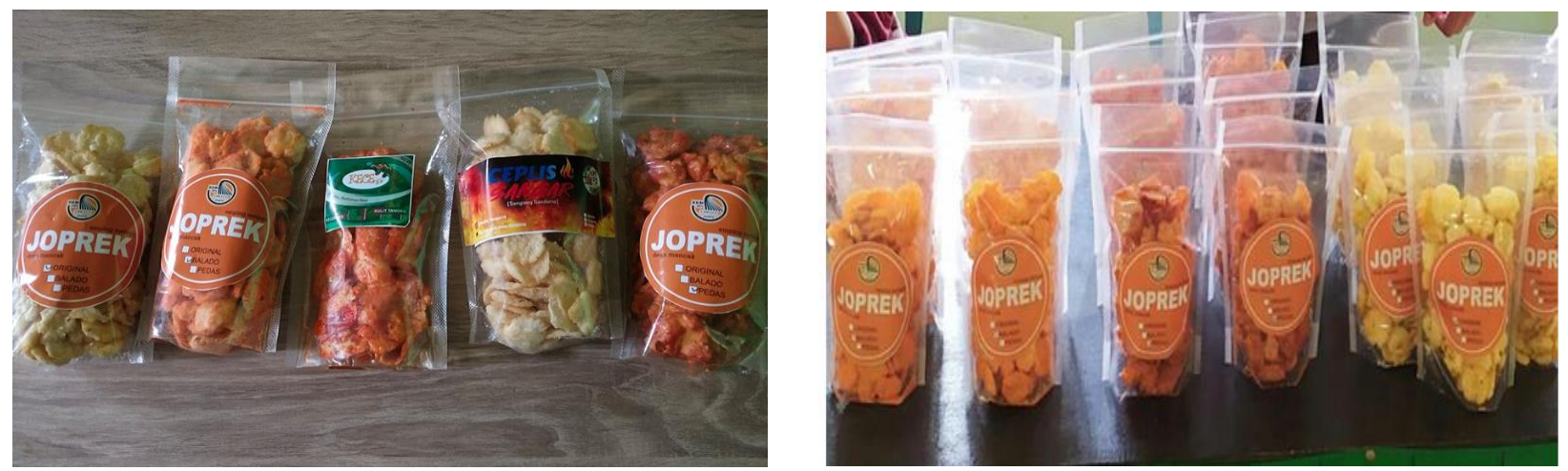

Gambar 5 : Produk yang sudah di Kemas

Dalam Pameran Produk yang dilakukan di Gedung Koperasi dan UKM Desa Mancak yang dihadiri oleh masyarakat mancak, pejabat kecamatan dan berbagai utusan desa dari kecamatan mancak dan dihadiri juga oleh Ibu Vita Agustini, dari Dinas Koperasi Perindustrian dan Perdagangan (DISKOPERINDANG) menegaskanPengembangan Produk Lokal Sebagai Produk Unggulan Pariwisata Kabupaten Serang.
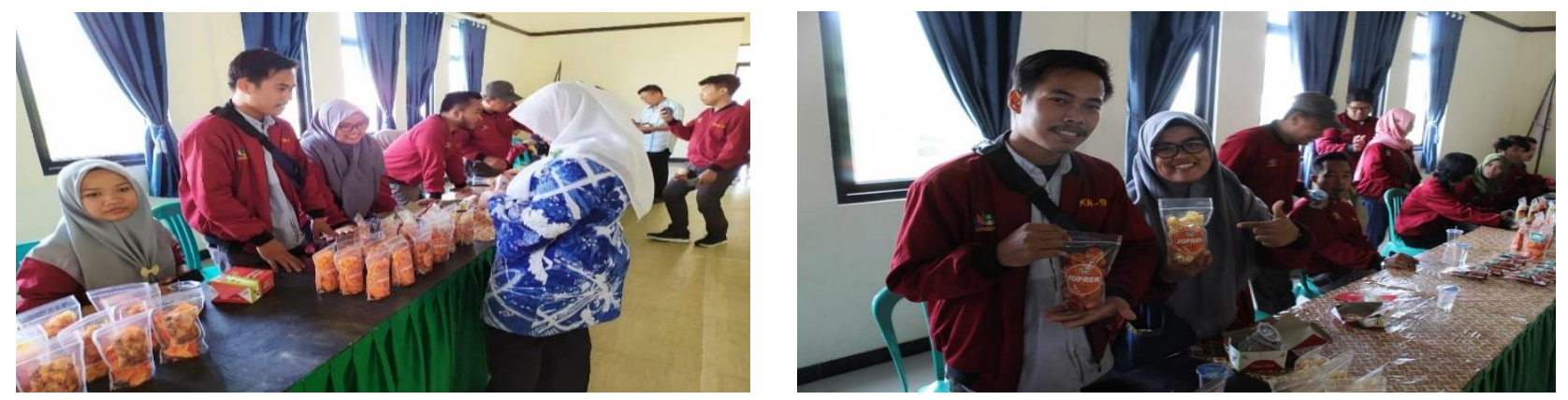

Gambar 6 : Pameran Hasil Produk

Dalam Pameran tersebut Sekdes Desa Mancak mengucapkan banyak terimakasih dan begitupun kami mengucapkan banyak terimkasih atas kerjasamanya dalam program ini dan menghasilkan sebuah produk yang bisa membantu masyarakat desa. 

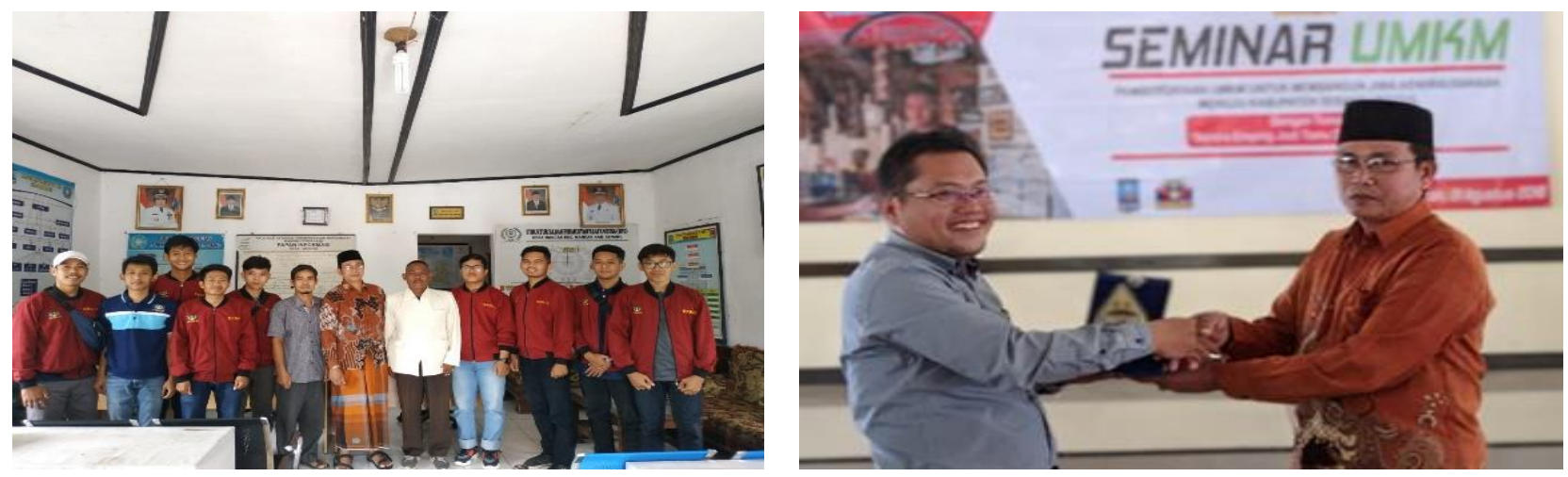

Gambar 7. Ucapan Terimkasih kepada Masyarakat dan Sekdes Desa Mancak

\section{KESIMPULAN}

Setelah dilaksanakan kegiatan pengabdian kepada masyarakat dengan tema "Teknologi Branding Dalam Pengemasan Produk Emping Melinjo Upaya Meningkatkan Partisipasi, Keterampilan dan Pemasaran Masyarakat Pedesaan", maka terjadi peningkatan pemahaman, pengetahuan dan keterampilan masyarakat tentang bagaimana mengolah kegiatan branding dalam pengemasan produk serta lebih memperhatikan merek emping melinjo.

Dengan meningkatkan pemahaman,pengetahuan dan keterampilan dalam mengolah kegatan branding dalam pengemasan produk yang berguna dan memiliki nilai jual tinggi dengan harapannya masyarakat desa mancak, kecamatan mancak menjadi masyarakat yang produktif dan kereatif. Dengan adanya kegiatan pengabdian kepada masyarakat yang singkat perlu ditambah waktunya dan biaya agar kegaiatn lebih menyeluruh.

\section{DAFTAR PUSTAKA}

Desa Mancak, Kecamatan Mancak http://mancak.sideka.id/ diakses tanggal 6 September 2019

Kolter, Philip dan Kevin Lane Keller. 2009. Manajmen Pemasaran, Edisi Ketiga Belas. Jakarta : Penerbit Erlangga

Marianne Rosner Klimchuk, \& Sandra A. Krasovec. 2007. Desain Kemasan. Jakarta : Penerbit Erlangga.

Marianne Rosner Klimchuk, \& Sandra A. Krasovec. (2007). Desain Kemasan. Jakarta

Naisbitt, 2002. High tech high touch. Bandung: Mizan

Panduan Penelitian dan Pengabdian kepada masyarakat edisi XII, Direktorat Riset dan Pengabdian

Masyarakat, Direktorat Jenderal Penguatan Riset dan Pengembangan, Kementerian Riset, Teknologi, dan Pendidikan Tinggi tahun 2018

Undang-undang Merek Dan Indikasi Geografis Nomor 20 Tahun 2016 